\title{
An Introductory Bibliography for the Study of the Dead Sea Scrolls Text Editions and Tools for Study
}

\author{
HENRYK DRAWNEL \\ Institute of Biblical Studies, John Paul II Catholic University of Lublin \\ e-mail: hdrawnel@kul.pl \\ ORCID: 0000-0003-4425-315X
}

\begin{abstract}
The present article contains an introductory bibliography for the use of students of the Dead Sea Scrolls. It focuses on the editions of the manuscripts and additional exegetical tools as well as resources necessary in initial and further research. Short notes added to some entries are intended to help the interested reader to get acquainted with the content and relevance of a particular publication. The second part of the article includes an updated list of archeological, philological and bibliographical sources needed for a proper exegetical approach to the scrolls.
\end{abstract}

Keywords: Second Temple Judaism, Qumran, bibliography, text editions, tools for research

\section{TEXT EDITIONS}

\section{Discoveries in the Judaean Desert Series}

\footnotetext{
T his offical series begun in 1955 and ended in 2010. It includes most of the manuscripts discovered at Qumran and elsewhere in the Judaean Desert. Aramaic, Hebrew and Greek are published therein together with paleographic description and datation, English or French translations and philological notes. Each volume possesses an index or concordance of the vocabulary found in the volume. Some volumes contain archeological notes. After 1991, an enlarged circle of manuscript editors based their editions of texts that were assigned to them on the earlier, often provisory, transcriptions of the first team caring for the editorial work, especially Józef T. Milik, J. Strugnell, F. M. Cross and others. Volume $\mathrm{V}$ must be used with caution; the reader has to take into account the corrective notes by John Strugnell.
} 


\section{QUMRAN CAVE 1}

DJD I: Barthélemy, D. - Milik, J.T., Qumran Cave I (with contributions by R. de Vaux et al.) (DJD 1; Oxford: Clarendon Press 1955, repr. 2003).

(Biblical, pseudepigraphical, liturgical and juridic texts)

Trever, J.C., „Completion of the Publication of Some Fragments from Qumrân Cave I", $\operatorname{RevQ} 19$ (1965) 323-336.

(Publication of the photographs 1QDn ${ }^{\mathrm{a}}, 1 \mathrm{QDn}{ }^{\mathrm{b}}, 1 \mathrm{QNoe}$ [1Q19 $\left.{ }^{\mathrm{bis}}\right]$, 1QPrayers Frgs. [1Q34 $\left.{ }^{\text {bis }}\right]$ )

\section{QUMRAN CAVES 2Q, 3Q, 5Q, 6Q, $7 Q$ to $10 Q$}

DJD 3: Baillet, M. - Milik, J.T. - de Vaux, R., Les 'Petites Grottes' de Qumrân: Exploration de la falaise: Les grottes 2Q, 3Q, 5Q, 6Q, 7Q à 10Q; Le rouleau de cuivre (avec une contribution de H.W. Baker) (DJDJ 3; Oxford: Clarendon Press 1962) I-II.

(Biblical and pseudepigraphical texts, copper scroll)

\section{QUMRAN CAVE 4}

DJD 5: Allegro, J.M., Qumran Cave 4. I. (4Q158-4Q186) (with the collaboration of A.A. Anderson) (DJDJ 5; Oxford: Clarendon Press 1968).

(Peshers to Isaiah, Hosea, Micah [?], Nahum, Zephaniah, Psalms; Florilegium, Testimonia, Tanhumim, Catena [A and B], Lamentations, Ages of Creation)

Strugnell, J., „Notes en marge du volume V des 'Discoveries in the Judaean Desert of Jordan"”, RevQ 7 (1970) 163-276.

(Contains numerous corrections of DJD 5 volume)

DJD 6: de Vaux, R. - Milik, J.T., Qumrân Grotte 4. II/1. Archéologie. II/2. Tefillin, Mezuzot et Targums (4Q128-4Q157) (avec des contributions de J.W.B. Barns - J. Carswell) (DJD 6; Oxford: Clarendon 1977).

DJD 7: Baillet, M., Qumrân Grotte 4. III. (4Q482-4Q520) (DJD 7; Oxford: Clarendon Press 1982).

(Pseudepigrapha, War Scroll, liturgical and legal texts)

\section{Biblical Scrolls}

DJD 9: Skehan, P.W. - Ulrich, E.C. - Sanderson, J.E., Qumran Cave 4. IV. Palaeo-Hebrew and Greek Biblical Manuscripts (with a contribution by P.J. Parsons) (DJD 9; Oxford: Clarendon Press 1992).

DJD 12: Ulrich, E.C. et al., Qumran Cave 4. VII. Genesis to Numbers (DJD 12; Oxford: Clarendon Press 1994). 
DJD 14: Ulrich, E.C. - Cross, F.M. - Crawford White, S., Qumran Cave 4. IX. Deuteronomy, Joshua, Judges, Kings (DJD 14; Oxford: Clarendon 1995).

DJD 15: Ulrich, E.C. et al., Qumran Cave 4. X. The Prophets (with the collaboration of C.M. Murphy - C. Niccum) (DJD 15; Oxford: Clarendon Press 1997).

DJD 16: Ulrich, E.C. et al., Qumran Cave 4. XI. Psalms to Chronicles (DJD 16; Oxford: Clarendon 2000).

DJD 17: Cross, F.M. et al., Qumran Cave 4. XII. 1-2 Samuel (DJD 17; Oxford: Clarendon 2005).

DJD 32: Ulrich, E. - Flint, P. W. - Abegg, M.G., Qumran Cave 1. II. The Isaiah Scrolls. 1. Plates and Transcriptions. 2. Introductions, Commentary, and Textual Variants (DJD 32; Oxford: Clarendon Press 2010).

\section{Parabiblical Texts}

DJD 13: Attridge, H.W. et al., Qumran Cave 4. VIII/1. Parabiblical Texts (in consultation with J.C. VanderKam) (DJD 13; Oxford: Clarendon Press 1994).

DJD 19: Broshi, M. et al., Qumran Cave 4. XIV/2. Parabiblical Texts (in consultation with J.C. VanderKam) (DJD 19; Oxford: Clarendon Press 1995).

DJD 22: Brooke, G. J. et al., Qumran Cave 4. XVII/3. Parabiblical Texts (in consultation with J. C. VanderKam: Partially Based on Earlier Transcriptions by J.T. Milik - J. Strugnell) (DJD 22; Oxford: Clarendon Press 1996).

DJD 30: Dimant, D., Qumran Cave 4. XXI. Parabiblical Texts. 4. PseudoProphetic Texts (Partially Based on Earlier Transcriptions by J. Strugnell) (DJD 30; Oxford: Clarendon 2001).

\section{Poetical and Liturgical Texts}

DJD 11: Eshel, E. et al., Qumran Cave 4. VI/1. Poetical and Liturgical Texts (in consultation with J.C. VanderKam - M. Brady) (DJD 11; Oxford: Clarendon Press 1998).

DJD 29: Chazon, E.G. et al., Qumran Cave 4. XX/2. Poetical and Liturgical Texts (in consultation with J.C. VanderKam - M. Brady. Based in Part on Earlier Transcriptions and Comments by J. Strugnell) (DJD 29; Oxford: Clarendon Press 1999).

DJD 40: Stegemann, H. - Schuller, E., 1QHodayot ${ }^{\mathrm{a}}$ : With Incorporation of 1 QHodayot $^{\mathrm{b}}$ and 4 QHodayot $^{\mathrm{a}-\mathrm{f}}$ (translation of text by C. Newsom; in consultation with J.C. VanderKam - M. Brady) (DJD 40; Oxford: Clarendon Press 2009).

\section{Legal and Calendrical Texts}

DJD 10: Qimron, E. - Strugnell, J., Qumran Cave 4. V. Miqșat Ma 'aśe Ha-Torah (in consultation with Y. Sussmann; with contributions by Y. Sussmann A. Yardeni) (DJD 10; Oxford: Clarendon Press 1994). 
DJD 18: Baumgarten, J.M., Qumran Cave 4. XIII. The Damascus Document (4Q266-273) (on the basis of transcriptions by J.T. Milik, with Contributions by S. Pfann - A. Yardeni) (DJD 18; Oxford: Clarendon Press 1996).

DJD 21: Talmon, S. - Ben-Dov, J. - Glessmer, U., Qumran Cave 4. XVI. Calendrical Texts (DJD 21; Oxford: Clarendon Press 2001).

DJD 35: Baumgarten, J. et al., Qumran Cave 4. XXV. Halakhic Texts (Based in Part on Earlier Transcriptions by Jósef T. Milik) (DJD 35; Oxford: Clarendon 1999).

\section{Sapiential Texts}

DJD 20: Elgvin, T. et al., Qumran Cave 4. XV/1. Sapiential Texts (in consultation with J.A. Fitzmyer: partially based on earlier transcriptions by J.T. Milik - J. Strugnell) (DJD 20; Oxford: Clarendon Press 1997).

DJD 34: Strugnell, J. - Harrington, D., Qumran Cave 4. XXIV. Sapiential Texts. 2. 4QInstruction (Mûsār Lě Mēvîn): 4Q415 ff. (with a re-edition of 1Q26 and an Edition of 4Q423 by T. Elgvin; in consultation with J.A. Fitzmyer) (DJD 34; Oxford: Clarendon 1999).

\section{Rule of the Congregation}

DJD 26: Alexander, P.S. - Vermes, G., Qumran Cave 4. XIX. Serekh ha-Yahad and Two Related Texts (DJD 26; Oxford: Clarendon Press 1998).

\section{Pseudepigraphic Hebrew and Aramaic Texts}

DJD 25: Puech, É., Qumrân Grotte 4. XVIII. Textes hébreux (4Q521-4Q528, 4Q576-4Q579) (DJD 25; Oxford: Clarendon Press 1998).

(Messianic Apocalypse, apocryphon of Josua (?), 4QJonathan, Temple Scroll (4Q524), 4QBlessings, a Testament (?), Liturgical Work, Genesis ${ }^{\mathrm{n}}$ (4Q576), Text Mentioning the Flood, Historical Composition B, Hymnic Composition)

DJD 31: Puech, É., Qumrân Grotte 4. XXII. Textes araméens. 1. 4Q529-549 (DJD 31; Oxford: Clarendon 2001).

(Words of Michael, Book of Giants, Birth of Noah, Testaments of Jacob, Judah and Joseph; Levi Apocryphon, Testament of Qahat, Visions of Amram)

DJD37: Puech, É., Qumrân Grotte 4.XXVII. Textes araméens. 2.4Q550-4Q575a, 4Q580-4Q587 et appendices (DJD 37; Oxford: Clarendon 2009).

(Jews at the Persian Court, an Account, Four Kingdoms, New Jerusalem, Prophetic and Visionary Texts, Biblical Chronology, a Magic Booklet, Horoscope, other fragmentary texts) 


\section{Unidentified}

DJD 33: Pike, D.M. - Skinner, A.C., Qumran Cave 4. XXIII. Unidentified Fragments (with a contribution by T.L. Szink; in consultation with J.C. VanderKam - M. Brady) (DJD 33; Oxford: Clarendon Press 2001).

\section{Cryptic and Miscellanea}

DJD 36: Pfann, S.J. et al., Qumran Cave 4. XXVI/1. Cryptic Texts and Miscellanea (in consultation with J.C. Vanderkam - M. Brady) (DJD 36; Oxford: Clarendon 2000).

DJD 38: Charlesworth, J.H. et al., Miscellaneous Texts From the Judaean Desert (in consultation with J.C. Vanderkam - M. Brady) (DJD 38; Oxford: Clarendon 2000).

\section{CAVE 11}

DJD 4: Sanders, J.A., The Psalms Scroll of Qumrân Cave 11 (11QPs $s^{\mathrm{a}}$ (DJDJ 4; Oxford: Clarendon Press 1965).

DJD 23: García Martinez, F. - Tigchelaar, E.J.C. - Van der Woude, A.S., Qumran Cave 11. II. 11Q2-18, 11Q20-31 (incorporating earlier editions by J.P.M. van der Ploeg; with a contribution by E. Herbert) (DJD 23; Oxford: Clarendon Press 1998).

\section{NAHAL ḤEVER}

DJD 8: Tov, E. - Kraft, R.A. - Parsons, P.J., The Greek Minor Prophets Scroll from Nahal Hever (8HevXIIgr) (DJD 8. The Seiyâl Collection 1; Oxford: Clarendon Press 1990).

DJD 27: Cotton, H.M. - Yardeni, A., Aramaic, Hebrew and Greek Documentary Texts from Nahal Hever and Other Sites: With Appendix Containing Alleged Qumran Texts (DJD 27. The Seiyâl Collection 2; Oxford: Clarendon Press 1997).

\section{WADI DALIYEH}

DJD 24: Leith, M. - Winn, J., Wadi Daliyeh I: The Wadi Daliyeh Seal Impressions (DJD 24; Oxford: Clarendon 1997).

DJD 28: Gropp, D.M. et al., Wadi Daliyeh II and Qumran Cave 4. XXVII/2. Miscellanea (in consultation with J.C. VanderKam - M. Brady) (DJD 28; Oxford: Clarendon Press 2001).

\section{WADI MURABBA`ÂT}

DJD 2: Benoit, P. - Milik, J.T. - de Vaux, R., Les Grottes de Murabba ât (avec des contributions de G.M. Crowfoot - E. Crowfoot - A. Grohmann) (DJD 2; Oxford: Clarendon Press 1961) I-II. 


\section{MANUSCRIPT LISTS, INDICES AND INTRODUCTION TO DJD}

DJD 39: Tov, E. et al., The Texts from the Judaean Desert: Indices and Introduction to the Discoveries in the Judaean Desert Series (DJD 39; Oxford: Clarendon 2002).

(This volume is a useful introduction to the texts published in the series. It contains an exhaustive list of the manuscripts with their previous names, catalogue numbers of the photographs, publication places of the manuscripts. A classification of the manuscripts according to their literary styles has also been added, along with a list of biblical texts, concordance of proper names, chronological list of the manuscripts mostly based on the editors' paleographic judgment, and some other appendices)

Tov, E., Revised Lists of the Texts from the Judaean Desert (Leiden: Brill 2010). (Corrected and updated list of the Dead Sea manuscripts)

Tov, E., „Appendix C: Texts from the Judean Desert”, The SBL Handbook of Style, 2ed ed. (Atlanta, GA: BL Press 2014) 269-330.

(Corrected and updated list of the Dead Sea manuscripts; for a provisional list of uprovenanced manuscripts that turned out on the antiquity market in the 21 st century, see E. Tigchelaar, „A Provisional List of Unprovenanced, Twenty-First Century, Dead Sea Scroll-like Fragments", DSD 24 (2017) 173-188)

\section{Qumran Cave 1}

\section{Isaiah (1QIsaa); Pesher to Habakuk (1QpHab); Community Rule (1QS)}

Burrows, M., The Dead Sea Scrolls of St. Mark's Monastery. I. The Isaiah Manuscript and the Habakkuk Commentary (eds. J.C. Trever - W.H. Brownlee) (New Haven, CT: American Schools of Oriental Research 1950).

(Introduction, transcription of the text and plates)

Burrows, M., The Dead Sea Scrolls of St. Mark's Monastery. II/2. Plates and Transcription of the Manual of Discipline (eds. J.C. Trever - W.H. Brownlee) (New Haven, CT: American Schools of Oriental Research 1951).

(Plates and text transcription; fascicle 1 has never been published)

Cross, F.M., Scrolls from Qumran Cave 1: The Great Isaiah Scroll. The Order of the Community. The Pesher to Habakkuk (From Photographs by John C. Trever) (Jerusalem: Albright Institute of Archaeology Research and the Shrine of the Book 1972).

Charlesworth, J.H. (ed.), The Dead Sea Scrolls: Rule of the Community: Photographic Multi-Language Edition (Philadelphia, PA: American Interfaith Institute/World Alliance 1996). 
Licht, J., The Rule Scroll: A Scroll from the Wilderness of Judaea 1QS, 1QS $1 Q S^{b}:$ Text, Introduction and Commentary (Jerusalem: The Bialik Institute 1965).

Parry, D.W. - Qimron, E., The Great Isaiah Scroll (1QIsa $)^{a}$ : A New Edition (STDJ 32; Leiden: Brill 1999).

Second Isaiah Scroll (1Q8=1QIsa $\left.{ }^{\mathrm{b}}\right)$, War Scroll (1Q33=1QM); Hodayot $\left(1 \mathrm{QH}^{\mathrm{a}}\right)$

Sukenik, E.L., אוצר המגלות הגנוזות (ed. N. Avigad) (Jerusalem: Mosad Bialik and Hebrew University 1954).

(Introduction in modern Hebrew, texts, plates)

Sukenik, E.L., The Dead Sea Scrolls of the Hebrew University (eds. Y. Yadin N. Avigad) (Jerusalem: Hebrew University - Mages Press 1955).

(An English version of the 1954 edition; introduction, texts, 58 plates)

Yadin, Y., מגילת מלחמת בני אור בבני חושך ממגילות מדבר יהודה (Jerusalem: Bialik Institute 1955).

(An annotated text of the War Scroll with an extensive introduction, without the plates)

Yadin, Y., The Scroll of the War of the Sons of Light against the Sons of Darkness (trans. B. and Ch. Rabin) (Oxford: Oxford University Press 1962).

(An English translation of the 1955 Hebrew edition)

\section{Genesis Apocryphon (1Q20)}

Avigad, N. - Yadin, Y., A Genesis Apocryphon: A Scroll from the Wilderness of Judaea: Description and Contents of the Scroll, Facsimiles, Transcription and Translation of Columns II, XIX-XXII (Jerusalem: Magnes Press 1956).

Fitzmyer, J.A., The Genesis Apocryphon of Qumran Cave 1 (1Q20): A Commentary, 3rd ed. (BibOr 18b; Rome: Biblical Institute Press 2004).

Greenfield, J.C. - Qimron, E., „Genesis Apocryphon Col. XII”, Studies in Qumran Aramaic (ed. T. Muraoka) (AbrNSup 3; Louvain: Peeters 1992) 70-77.

Machiela, D.A., The Dead Sea Genesis Apocryphon: A New Text and Translation with Introduction and Special Treatment of Columns 13-17 (STDJ 79; Leiden: Brill 2009).

Morgenstern, M. - Qimron, E. - Sivan, D., „The Hitherto Unpublished Columns of the Genesis Apocryphon", AbrN 33 (1995) 30-54. 


\section{Judaean Desert Studies and Related Publications (Naḥal Hever and Naḥal Mishmar)}

The series edited by the Hebrew University in Jerusalem contains the results of the archaeological excavations led by Yigael Yadin in the Desert of Judah. The texts published therein mostly stem from the Second Jewish revolt (132-135 AD).

Aharoni, Y., „The Expedition to the Judean Desert, 1960, Expedition B”, IEJ 11/1-2 (1961) 11-24 (cf. 22-24).

Aharoni, Y., „Expedition B - The Cave of Horror”, IEJ 12/3-4 (1962) 186-199.

Lewis, N. (ed.), The Documents from the Bar Kokhba Period in the Cave of Letters: Greek Papyri (JDS 2; Jerusalem: Israel Exploration Society - Hebrew University of Jerusalem - Shrine of the Book 1989).

Yadin, Y. et al., The Finds from the Bar Kokhba Period in the Cave of Letters (JDS 1; Jerusalem: Israel Exploration Society 1963).

Yadin, Y. - Greenfield, J.C., „Aramaic and Nabatean Signatures and Subscriptions", The Documents from the Bar Kokhba Period in the Cave of Letters (ed. N. Lewis) (JDS 2; Jerusalem: Israel Exploration Society - Hebrew University of Jerusalem - Shrine of the Book 1989) 135-149.

Yadin, Y., - Greenfield, J.C. - Yardeni, A., „Babatha's Ketubba”, IEJ 44/1-2 (1994) 75-101.

Yadin, Y., - Greenfield, J.C. - Yardeni, A., „A Deed of Gift in Aramaic Found in Nahal Hever: Papyrus Yadin 7”, ErIsr 25 (1996) 383-403 (in Hebrew).

Yadin, Y. et al., The Documents from the Bar Kokhba period in the Cave of Letters: Hebrew, Aramaic and Nabatean-Aramaic Papyri (JDS 3; Jerusalem: Israel Exploration Society - Hebrew University of Jerusalem - Shrine of the Book 2002).

\section{Naḥal Mishmar}

Bar-Adon, P., „The Expedition to the Judean Desert 1960. Expedition C”, IEJ 11/1-2 (1961) 25-30.

(Pl. 13E: fragment of a Hebrew papyrus)

Bar Adon, P., „Judean Desert Caves-The Nahal Mishmar Caves”, Encyclopedia of Archaeological Excavations in the Holy Land (eds. M. Avi-Yonah

- E. Stern) (Jerusalem: Israel Exploration Society 1977) III, 683-690 (cf. 690b).

Lifschitz, B., „The Greek Documents from Naḥal Șeelim and Naḥal Mishmar”, IEJ 11/1-2 (1961) 53-62.

Lifschitz, B., „Papyrus grecs du désert de Juda” Aeg 42 (1962) 240-256 (2 pls.). 


\section{Masada Reports}

Cotton, H.M. - Geiger, J., Masada II: The Yigael Yadin Excavations 1963-1965 Final Reports: The Latin and Greek Documents (The Masada Reports; Jerusalem: Israel Exploration Society - The Hebrew University of Jerusalem 1989).

Meshorer, Y., „The Coins of Masada”, Masada I: The Yigael Yadin Excavations 1963-1965 Final Reports (The Masada Reports; Jerusalem: Israel Exploration Society - The Hebrew University of Jerusalem 1989) 69-132.

Talmon, S. et al., „Hebrew Fragments form Masada”, Masada VI: The Yigael Yadin Excavations 1963-1965 Final Reports (The Masada Reports; Jerusalem: Israel Exploration Society - The Hebrew University of Jerusalem 1999) 1-149.

Yadin, Y., „The Ben Sira Scroll from Masada: Introduction, Emendations and Commentary", Masada VI: The Yigael Yadin Excavations 1963-1965: Final Reports (The Masada Reports; Jerusalem: Israel Exploration Society - The Hebrew University of Jerusalem 1999) 151-252.

Yadin, Y. - Naveh, J., „The Aramaic and Hebrew Ostraca and Jar Inscriptions”, Masada I: The Yigael Yadin Excavations 1963-1965. Final Reports (The Masada Reports; Jerusalem: Israel Exploration Society - The Hebrew University of Jerusalem 1989) 1-68.

\section{Other Editions}

The list that follows contains publications that in most cases are not included in the series listed above. The reader must be advised that the editorial work on the earlier editions of many scrolls has continued and will lead to new editions or articles comprising new readings, identifications or a different disposition of the fragments in a manuscript.

Aramaic Enoch (4Q201-202; 4Q204-211)

Drawnel, H., The Aramaic Astronomical Book (4Q208-4Q211) from Qumran: Text, Translation, and Commentary (Oxford: Oxford University Press 2011).

Drawnel, H., Qumran Cave 4: The Aramaic Books of Enoch: 4Q201, 4Q202, 4Q204, 4Q205, 4Q206, 4Q207, 4Q212 (in consultation with É. Puech) (Oxford: Oxford University Press 2019).

Milik, J.T., The Books of Enoch: Aramaic Fragments of Qumrân Cave 4 (with the collaboration of M. Black) (Oxford: Clarendon 1976).

(Editio princeps of the Aramaic fragments of 1 Enoch, with an extensive introduction and notes; it also contains fragmentary manuscripts of the Book of Giants) 
Muro, E.A., ,The Greek Fragments of Enoch from Qumran Cave 7 (7Q4, 7Q8, \& 7Q12 = 7QEn gr = Enoch 103:3-4, 7-8)", RevQ 18/2 (1997) 307-312.

Puech, É., „Sept fragments grecs de la Lettre d'Hénoch (1 Hén 100, 103 et 105) dans la grotte 7 de Qumrân (=7QHéngr)", RevQ 18/2 (1997) 313-323.

\section{Copper Scroll (3Q15)}

Brizemeure, D. - Lacoudre, N. - Puech, É., Le Rouleau de cuivre de la grotte 3 de Qumrân (3Q15): Expertise-Restauration-Epigraphie (STDJ 55; Leiden: Brill 2006) I-II.

\section{Damascus Document (Cairo Genizah)}

Broshi, M., The Damascus Document Reconsidered (Jerusalem: Israel Exploration Society \& Shrine of the Book, Israel Museum 1992).

Schechter, S., Documents of Jewish Sectaries. I. Fragments of a Zadokite Work (Cambridge: University Press 1910).

\section{Fragments from private collections}

Elgvin, T. - Davis, K. - Langlois, M. (eds.), Gleanings from the Caves: Dead Sea Scrolls and Artifacts from the Schøyen Collection (LSTS 71; London: Bloomsbury T\&T Clark 2016).

Eshel, E. - Eshel, H., „New Fragments from Qumran: 4QGen ${ }^{\mathrm{f}}$ 4QIsa ${ }^{\mathrm{b}}$, 4Q226, 8QGen, and XPapEnoch", DSD 12 (2005) 134-157.

(XPapEnoch is a modern forgery, see Davis et al., „Nine Dubious 'Dead Sea Scrolls' Fragments" below)

Davis, K. et al., „Nine Dubious 'Dead Sea Scrolls' Fragments from the Twenty-First Century", DSD 24 (2017) 189-228.

(Fragmentary manuscripts purportedly from Qumran preserved in the Schøyen collection turned out to be modern forgeries; on the same topic, see the unpublished paper by E. Tigchelaar, "Gleanings from the Caves? Really? On the Likelihood of Dead Sea Scrolls Forgeries in the Schøyen Collection”, 1-6, see https://www.academia.edu).

Tov, E. - Davis, K. - Duke, R., Dead Sea Scrolls Fragments in the Museum Collection (PMB 1; Leiden: Brill 2016)

(12 biblical fragments and one apocryphal from private collections; there are grounds to claim that some of these fragments are modern forgeries, see K. Davis, „Caves of Dispute: Patterns of Correspondence and Suspicion in the Post-2002 'Dead Sea Scrolls’ Fragments”, DSD 24 [2017] 229-270).

\section{Hirbet Mird}

Grohmann, A., Arabic Papyri from Hirbet el-Mird (Bibliothèque du Muséon 52; Leuven: Publications Universitaires 1963). 
Haelst, J. van, „Cinq textes provenant de Khirbet Mird”, Ancient Society 22 (1991) 297-317.

Milik, J.T., „Une inscription et une lettre en araméen christo-palestinien”, $R B 60$ (1953) 526-539.

Perrot, Ch., „Un fragment christo-Palestinien decouvert à Khirbet Mird”, $R B 70$ (1963) 506-555.

\section{Paleo-Hebrew Leviticus (11Q1)}

Freedman, D.N. - Mathews, K.A., The Paleo-Hebrew Leviticus Scroll (11QpaleoLev) (with contributions by R.S. Hanson) ([Philadelphia, PA]: American Schools of Oriental Research 1985).

Puech, É., „Notes en marge de 11 QpaléoLévitique: Le fragment L, des fragments inédits et une jarre de la grotte 11", RB 96 (1989) 161-183.

\section{Targum of Job (11Q10)}

Puech, É. - García Martínez, F., „Remarques sur la Colonne XXXVIII de 11 Q tg Job", RevQ 9/3 (1978) 401-407.

Sokoloff, M., The Targum to Job from Qumran Cave XI (Ramat-Gan: Bar-Ilan University Press 1974).

Van der Ploeg, J.P.M. - van der Woude, A.S., Le Targum de Job de la grotte XI de Qumrân (avec la collaboration de B. Jongeling) (KNAW; Leiden: Brill 1971).

\section{Tefillin}

Yadin, Y., Tefillin from Qumran (XQ Phyl 1-4) (Jerusalem: Israel Exploration Society 1969).

(unknown Qumran cave)

\section{Temple Scroll (11Q19)}

Qimron, E., The Temple Scroll: A Critical Edition with Extensive Reconstruction (bibliography by F. García Martínez) (JDS; Beer Sheva: Ben-Gurion University of the Negev Press - Jerusalem: Israel Exploration Society 1996).

Yadin, Y., The Temple Scroll (Jerusalem: Israel Exploration Society 1977) I-III (in Hebrew).

Yadin, Y., The Temple Scroll (Jerusalem: Israel Exploration Society 1983) I-III (English edition). 
11QPsalms ${ }^{\text {a }}$

Dahmen, U., Psalmen- und Psalter-Rezeption im Frühjudentum: Rekonstruktion, Textbestand, Struktur und Pragmatik der Psalmenrolle 11QPs aus Qumran (STDJ 99; Leiden: Brill 2003).

Sanders, J.A., The Dead Sea Psalms Scroll (Ithaca, NY: Cornell University Press 1967).

\section{Varia}

Baillet, M., „Un livret magique en christo-palestinien à l'université de Louvain”, Mus 76 (1963) 375-401.

Kister, M., „Newly-Identified Fragments of the Book of Jubilees: Jub. 23:21-23, 30-31", $\operatorname{RevQ~12/4~(1987)~529-536.~}$

Puech, É., „Fragment d'un rouleau de la Genèse provenant du Désert de Juda”, $\operatorname{RevQ~10/2~(1980)~163-166.~}$

Starcky, J., ,Un contrat nabatéen sur papyrus”, RB 61 (1954) 161-181.

\section{Princeton Theological Seminary Dead Sea Scrolls Project}

Charlesworth, J.H. et al., The Dead Sea Scrolls: Hebrew, Aramaic and Greek Texts with English Translations. I. Rule of the Community and Related Documents (PTSDSSP 1; Tübingen: Mohr Siebeck - Louisville, KY: Westminster/ John Knox Press 1994).

Charlesworth, J.H. et al., The Dead Sea Scrolls: Hebrew, Aramaic and Greek Texts with English Translations. II. Damascus Document, War Scroll, and Related Documents (PTSDSSP 2; Tübingen: Mohr Siebeck - Louisville, KY: Westminster/John Knox Press 1995).

Charlesworth, J.H. et al., The Dead Sea Scrolls: Hebrew, Aramaic and Greek Texts with English Translations. III. Damascus Document II, Some Works of the Torah, and Related Documents (PTSDSSP 3; Tübingen: Mohr Siebeck Louisville, KY: Westminster/John Knox Press 2006).

Charlesworth, J.H. et al., The Dead Sea Scrolls: Hebrew, Aramaic and Greek Texts with English Translations. IVA. Pseudepigraphic and Non-Masoretic Psalms and Prayers (PTSDSSP 4A; Tübingen: Mohr Siebeck - Louisville, KY: Westminster/John Knox Press 1997).

Charlesworth, J.H. et al., The Dead Sea Scrolls: Hebrew, Aramaic and Greek Texts with English Translations. IVB. Angelic Liturgy: Songs of the Sabbath Sacrifice (PTSDSSP 4B; Tübingen: Mohr Siebeck - Louisville, KY: Westminster/John Knox Press 1999). 
Charlesworth, J.H. et al., The Dead Sea Scrolls: Hebrew, Aramaic and Greek Texts with English Translations. VIB. Pesharim, Other Commentaries, and Related Documents (PTSDSSP 6B; Tübingen: Mohr Siebeck - Louisville, KY: Westminster/John Knox Press 2002).

Charlesworth, J.H. et al., The Dead Sea Scrolls: Hebrew, Aramaic and Greek Texts with English Translations. V. Temple Scroll and Related Documents (PTSDSSP 7; Tübingen: Mohr Siebeck - Louisville, KY: Westminster/John Knox Press 2011).

\section{Comprehensive Editions}

Beyer, K., Die aramäischen Texte vom Toten Meer samt den Inschriften aus Palästina, dem Testament Levis aus der Kairoer Genisa, der Fastenrolle und den alten talmudischen Zitaten (Göttingen: Vandenhoeck \& Ruprecht 1984-2004) I-III.

(Volume 1 [1984] contains a diachronic overview of Aramaic, notes on the grammar of Qumran Aramaic and Aramaic-German dictionary with a German-Aramaic index. Later volumes publish additional texts and supplement the notes on grammar and vocabulary)

Dimant, D. - Parry, D.W., Dead Sea Scrolls Handbook (in association with G.I. Clements) (Leiden: Brill 2015).

García Martínez, F. - Tigchelaar, E.J.C., The Dead Sea Scrolls: Study Edition (Leiden: Brill 2000) I-II.

Ego, B. et al., Biblia Qumranica. IIIB. Minor Prophets (Leiden - Boston, MA: Brill 2005).

(Synoptic edition of the Qumran fragments with the Masoretic text, the Septuagint, the Samaritan Pentateuch, and the commentaries from the Qumran collection)

Parry, D.W. - Tov, E. - Clements, G.I., The Dead Sea Scrolls Reader. I. Texts Concerned with Religious Law, Exegetical Texts and Parabliblical Texts. II. Calendrical Texts and Sapiential Texts, Poetic and Liturgical Texts, Additional Genres and Uclassified Texts, 2nd ed. (Leiden: Brill 2014).

(Mostly Qumran texts classified according the literary genre and based on the DJD series)

Ulrich, E. (ed.), The Biblical Qumran Scrolls: Transcriptions and Textual Variants (VTSup 134; Leiden: Brill 2010).

(Biblical texts published in different volumes of the DJD series, presented here with textual variants) 


\section{SECONDARY LITERATURE}

\section{Archeology}

Bar-Adon, P., The Cave of the Treasure: The Finds from the Caves in Nahal Mishmar (Judean Desert Studies; Jerusalem: Israel Exploration Society 1980).

Cross, F.M., - Milik, J.T., ,Explorations in the Judaean Buqe 'ah”, BASOR 142 (1956) 5-17.

Davies, P.R., „How Not to Do Archaeology: The Story of Qumran”, BA 51 (1988) 203-207.

Donceel, R., „Khirbet Qumrân (Palestine): Le Locus 130 et ses vestiges d'activité artisanal", QC 13/1 (2005) 1-67.

Fidanzio, M. (ed.), The Caves of Qumran: Proceedings of the International Conference, Lugano 2014 (STDJ 118; Leiden: Brill 2017).

Frey, J. - Claussen, C. - Kessler, N., Qumran und die Archäologie: Texte und Kontexte (WUNT 278; Tübingen: Mohr Siebeck 2011).

Hirschfeld, Y., Qumran in Context: Reassessing the Archaeological Evidence (Peabody, MA: Hendrickson 2004).

Humbert, J.-B. - Chambon, A., Fouilles de Khirbet Qumrân et de Ä̈n Feshkha. I. Album de photographies. Répertoire du fonds photographique. Synthèse des notes de chantier du Père Roland de Vaux OP (NTOA. Series Archaeologica 1; Fribourg: Éditions Universitaires 1994).

Humbert, J.-B. - Chambon, A. (eds.), The Excavations of Khirbet Qumrân et de 'Ain Feshkha: Synthesis of Roland de Vaux's Field Notes (transl. and rev. by S. J. Pfann) (NTOA. Series Archaeologica 1B; Fribourg: University Press 2003) IB.

Humbert, J.-B. - Gunneweg, J. (eds.), Fouilles de Khirbet Qumrân et de Ä̈n Feshkha. II. Études d'anthropologie, de physique et de chimie (NTOA. Series Archaeologica 3; Fribourg: Éditions Universitaires 2003).

Humbert, J.-B. - Chambon, A. - Młynaczyk, J., Khirbet Qumrân et Ä̈n Feshkha: Fouilles du P. Roland de Vaux. IIIA. L'archéologie de Qumrân: Reconsidération de l'interprétation. Corpus of the Lamps (NTOA. Series Archaeologica 5a; Göttingen: Vanderhoeck \& Ruprecht 2016).

Humbert, J.-B. (ed.), Khirbet Qumran and Ain Feshkha: Fouilles du P. Roland de Vaux (transl. D.E. Orton) (NTOA. Series Archaeologica 5a; Göttingen: Vanderhoeck \& Ruprecht 2019).

Lapp, P.W., Palestinian Ceramic Chronology: 200 B.C.-A.D. 70 (New Haven, CT: American Schools of Oriental Research 1961). 
Magen, Y. - Peleg, Y., The Qumran Excavations 1993-2004 (Jerusalem: Staff Officer of Archaeology - Civil Administration of Judea and Samaria 2007).

Magness, J., ,The Chronology of the Settlement at Qumran in the Herodian Period", DSD 2 (1995) 58-65.

Magness, J., The Archaeology of Qumran and the Dead Sea Scrolls (Grand Rapids, MI: Eerdmans 2002).

Magness, J., Debating Qumran: Collected Essays on Its Archaeology (Leuven: Peeters 2004).

Milik, J.T., „Le giarre dei manoscritti della grotta del Mar Morto e dell'Egitto Tolemaico", Bib 31 (1950) 504-508.

Mizzi, D. - Magness, J., ,Was Qumran Abandoned at the End of the First Century BCE?", JBL (2016) 301-320.

Stacey, D. - Doudna, G. (eds.), Qumran Revisited: A Reassessment of the Archaeology of the Site and its Texts (BAR International Series 2520; Oxford: Archaeopress 2013).

Vaux, R. de, „La grotte des manuscrits hébreux”, RB 56 (1949) 586-609.

Vaux, R. de, „Les manuscrits de Qumrân et l'archéologie”, RB 66 (1959) 87-110.

Vaux, R. de, „Archéologie”, Les grottes de Murabba ât (eds. P. Benoit, J.T. Milik - R. de Vaux) (DJD 2; Oxford: Clarendon 1961) II, 3-63.

Vaux, R. de, Archaeology and the Dead Sea Scrolls, revised ed. in an English trans. (The Schweich Lectures 1959; Oxford: Oxford University Press 1973).

Vaux, R. de, „Qumrân Grotte 4. II/1. Archéologie” (avec des contributions de J.W. Barns - J. Carswell), Qumran Grotte 4. II/1. Archéologie. II/2. Tefillin, Mezuzot et Targums (4Q128-4Q157) (eds. R. de Vaux - J.T. Milik) (DJD 6; Oxford: Clarendon 1977) 1-29.

\section{Paleography and Modern Technology}

Avigad, N., „The Paleography of the Dead Sea Scrolls and Related Documents”, Aspects of the Dead Sea Scrolls (eds. Ch. Rabin - Y. Yadin) (ScrHier 4; Jerusalem: Magnes 1958) 56-87.

Cross, F.M., „The Development of the Jewish Scripts”, The Bible and the Ancient Near East: Essays in Honor of William Foxwell Albright (ed. G.E. Wright) (Garden City, NY: Doubleday 1961) 133-202.

(The most comprehensive, historical and typological study of the Qumran palaeography)

Cross, F.M., „Paleography and the Dead Sea Scrolls”, The Dead Sea Scrolls after Fifty Years: A Comprehensive Assessment (eds. P.W. Flint - J.C. VanderKam) (Leiden: Brill 1998) I, 379-402 (pl. 9-14). 
Cross, F.M., „Paleography”, Encyclopedia of the Dead Sea Scrolls (eds. L.H. Schiffman - J.C. VanderKam) (New York, NY: Oxford University Press 2000) II, 629-634.

Lavee, T., „Computer Analysis of the Dead Sea Scroll Manuscripts” (M.A. thesis; Tel Aviv University 2013), http://www.cs.tau.ac.il/thesis/thesis/Lavee. Tamar-MSc.Thesis.pdf.

Lundberg, M.J. - Zuckerman, B., „When Images Meet: The Potential of Photographic and Computer Imaging Technology for the Study of the Copper Scroll”, Copper Scroll Studies (eds. G.J. Brooke - P.R. Davies) (JSPSup 40; Sheffield: Sheffield Academic Press 2002) 45-57.

McLean, M., „The Use and Development of Palaeo-Hebrew in the Hellenistic and Roman Periods", (unpubl. Ph.D. diss.; Cambridge, MA: Harvard University 1982).

Martin, M., The Scribal Character of the Dead Sea Scrolls (Bibliothèque du Muséon 44-45; Louvain: Publications Universitaires 1958) I-II.

Puech, É., „La paléographie des manuscrits de la mer Morte”, The Caves of Qumran: Proceedings of the International Conference, Lugano 2014 (ed. M. Fidanzio) (STDJ 118; Leiden: Brill 2016) 96-105.

Rasmussen, K.L. et al., ,The Effects of Possible Contamination on the Radiocarbon Dating of the Dead Sea Scrolls I: Castor Oil', Radiocarbon 43 (2001) 127-132.

Rasmussen, K.L. et al., „On the Age and Content of Jar-35 - A Sealed and Intact Storage Jar Found on the Southern Plateau of Qumran", Archaeometry 53 (2011) 791-808.

Steudel, A., „Assembling and Reconstructing Manuscripts”, The Dead Sea Scrolls after Fifty Years: A Comprehensive Assessment (eds. P.W. Flint - J.C. VanderKam) (Leiden: Brill 1998) I, 516-534.

Tov, E., Scribal Practices and Approaches Reflected in the Texts Found in the Judean Desert (STDJ 54; Leiden: Brill 2004).

Zuckerman, B., „Bringing the Dead Sea Scrolls Back to Life: A New Evaluation of Photographic and Electronic Imaging of the Dead Sea Scrolls", DSD 3 (1996) 178-207.

Zuckerman, B., „The Dynamics of Change in the Computer Imaging of the Dead Sea Scrolls and Other Ancient Inscriptions", Rediscovering the Dead Sea Scrolls: An Assessment of Old and New Approaches and Methods (ed. M.L. Grossman) (Grand Rapids, MI: Eerdmans 2010) 69-88.

Zuckerman, B. - Levy, A. - Lundberg, M., „A Methodology for the Digital Reconstruction of Dead Sea Scroll Fragmentary Remains", Dead Sea Scrolls Fragments in the Museum Collection (eds. E. Tov - K. Davis - R. Duke) (PMB 1; Leiden: Brill 2016) 36-58. 


\section{Philology}

\section{Qumran Hebrew}

Fassberg, S. - Bar-Asher, M. - Clements, R., Hebrew in the Second Temple Period: The Hebrew of the Dead Sea Scrolls and of Other Contemporary Sources (STDJ 108; Leiden: Brill 2013).

Geiger, G., Das hebräische Partizip in den Texten aus der judäischen Wüste (STDJ 101; Leiden: Brill 2012).

Joosten, J. - Machiela, D. - Rey, J.-S., The Reconfiguration of Hebrew in the Hellenistic Period (STDJ 124; Boston: Brill 2018).

Kutscher, E.Y., The Language and Linguistic Background of the Isaiah Scroll (Jerusalem: Magness - Hebrew University 1959) (in Hebrew).

Kutscher, E.Y., The Language and Linguistic Background of the Isaiah Scroll (I QIsa $a^{a}$ (STDJ 6; Leiden: Brill 1974).

Kutscher, E.Y., The Language and Linguistic Background of the Isaiah Scroll $\left(I\right.$ QIsa $\left.^{a}\right)$ (indices and corrections by E. Qimron) (STDJ 6a; Leiden: Brill 1979).

Muraoka, T. - Elwolde, J.F. (eds.), The Hebrew of the Dead Sea Scrolls and Ben Sira (STDJ 26; Leiden: Brill 1997).

Qimron, E., The Hebrew of the Dead Sea Scrolls (HSS 29; Atlanta, GA: Scholars Press 1986).

Qimron, E., A Grammar of the Hebrew of the Dead Sea Scrolls (Jerusalem: Yad Yizhak Ben-Zvi 2018).

(An expanded edition of Qimron 1986)

Penner, K.M., The Verbal System of the Dead Sea Scrolls: Tense, Aspect, and Modality in Qumran Hebrew Texts (SSN 64; Leiden: Brill 2015).

Reymond, E.D., Qumran Hebrew: An Overview of Orthography, Phonology, and Morphology (RBS 76; Atlanta, GA: Society of Biblical Literature 2014).

Tigchelaar, E.J.C. - van Hecke, P. (eds.), Hebrew of the Late Second Temple Period (STDJ 114; Leiden: Brill 2015).

\section{Qumran Aramaic}

Cook, E.M., „The Aramaic of the Dead Sea Scrolls”, The Dead Sea Scrolls after Fifty Years: A Comprehensive Assessment (eds. P.W. Flint - J.C. VanderKam) (Leiden: Brill 1998) I, 359-378.

Cook, E.M., „The Causative Internal Passive in Qumran Aramaic”, AS 8 (2010) 5-12.

Fassberg, S.E., „Salient Features of the Verbal System in the Aramaic Dead Sea Scrolls", Aramaica Qumranica: Proceedings of the Conference on the Aramaic Texts from Qumran in Aix-en-Provence 30 June - 2 July 2008 (eds. D. Stökl Ben Ezra - K. Bertholet) (STDJ 94; Leiden: Brill 2010) 65-78. 
Fassberg, S.E., ,lhw' and Related Verbal Forms in Biblical and Qumran Aramaic in the Light of Aramaic Dialectology", In Memoriam John Strugnell: Four Studies (eds. M. Sigrist - K. Stephens) (CahRB 84; Pendé: Gabalda 2015) 7-18.

Greenfield, J.C., „The Infinitive in the Aramaic Documents from the Judean Desert", Studies on Hebrew and Other Semitic Languages: Presented to Professor Chaim Rabin on the Occasion of his Seventy-Fifth Birthday (eds. M. Goshen-Gottstein - S. Morag - S. Kogut) (Jerusalem: Akademon Press 1990) 77-81 (in Hebrew).

Kutscher, E.Y., „The Language of the 'Genesis Apocryphon': A Preliminary Study”, Aspects of the Dead Sea Scrolls (eds. Ch. Rabin-Y. Yadin) (ScrHier 4; Jerusalem: Magnes 1958) 1-35.

Muraoka, T., „Notes on the Aramaic of the Genesis Apocryphon”, $\operatorname{RevQ~8/1~}$ (1972) 7-51.

Muraoka, T., „Further Notes on the Aramaic of the 'Genesis Apocryphon'”, RevQ 16/1 (1993) 39-48.

Muraoka, T. (ed.), Studies in Qumran Aramaic (AbrNSup 3; Louvain: Peeters 1992).

Muraoka, T., A Grammar of Qumran Aramaic (ANESSup 38; Leuven: Peeters 2011).

Schattner-Rieser, U., L'araméen des manuscrits de la mer Morte. I. Grammaire (IELOA 5; Lausanne: Éditions du Zèbre 2004).

Stadel, C., Hebraismen in den aramäischen Texten vom Toten Meer (SHJSH 11; Heidelberg: Universitätsverlag Winter 2008).

\section{Greek at Qumran}

Richey, M., „,The Use of Greek at Qumran: Manuscript and Epigraphic Evidence for a Marginalized Language", DSD 19 (2012) 177-197.

\section{Dictionaries and Lexicons}

Comprehensive Aramaic Lexicon (http://cal.huc.edu/)

(lexicon and database; lemmata from all periods of language history, concordances, bibliographies; the project is unfinished, and not all lexemes have been included)

Clines, D.J.A. (ed.), The Dictionary of Classical Hebrew (Sheffield: Sheffield Academic Press 1993-2012) I-IX.

(It includes DSS vocabulary, Ben Sira, inscriptions and related texts; the first volume of the revised edition was published in 2018) 
Cook, E.M., Dictionary of Qumran Aramaic (Winona Lake, IN: Eisenbrauns 2015).

Fabry, H.J. - Dahmen, U. (eds.), Theologisches Wörterbuch zu den Qumrantexten (Stuttgart: Kohlhammer 2011-2016) I-III.

Kratz, R.G. - Steudel, A. - Kottsieper, I. (eds.), Hebräisches und aramäisches Wörterbuch zu den Texten vom Toten Meer: Einschließlich der Manuskripte aus der Kairoer Geniza. 1. Aleph-Beth. 2. Gimmel-Zajin (Berlin: De Gruyter 2017-2019).

Sander, R. - Mayerhofer, K., Retrograde Hebrew and Aramaic Dictionary (JAJS 1; Göttingen: Vandenhoeck \& Ruprecht 2010).

Sokoloff, M., A Dictionary of Jewish Babylonian Aramaic of the Talmudic and Geonic Periods (Dictionaries of Talmud, Midrash and Targum 3; Ramat Gan: Bar Ilan University Press 2002).

Sokoloff, M., A Dictionary of Jewish Palestinian Aramaic of the Byzantine Period, 2nd ed. (Dictionaries of Talmud, Midrash and Targum; Ramat Gan: Bar Ilan University Press 2002).

Sokoloff, M., A Syriac Lexicon: A Translation from the Latin, Correction, Expansion, and Update of C. Brockelmann's Lexicon Syriacum (Winona Lake, IN: Eisenbrauns 2009).

Tal, A., A Dictionary of Samaritan Aramaic (HdO 1. Der Nahe und Mittlere Osten 50; Leiden: Brill 2000) I-II.

\section{Concordances}

Abegg, M.G. - Bowley, J.E. - Cook, E.M., The Dead Sea Scrolls Concordance. I. The Non-Biblical Texts from Qumran (in consultation with E. Tov) (Leiden: Brill 2003).

(Aramaic Concordance, part. 2, pp. 773-946; Greek Concordance, pp. 94750; Appendix I; Concordance of Signs for Numbers: Greek [p. 953], Aramaic [pp. 953-956]; Appendix II: Typographical and Transcriptional Errors in the Text Editions, pp. 957-958. DJD 37 [2009], DJD 40 [2009], Drawnel, The Aramaic Astronomical Book, Drawnel, Qumran Cave 4 were published later than the concordance)

Abegg, M.G. - Bowley, J.E. - Cook, E.M., The Dead Sea Scrolls Concordance. II. The Non-Qumran Documents and Texts (in consultation with E. Tov) (Leiden: Brill 2016).

(Appendix I: pp. 165-244: Greek Concordance, followed by concordance of symbols and numerals: Greek, pp. 247-252, Aramaic/Hebrew, pp. 253-255; Appendix II: Masada Letter Tags, pp. 256-260; Appendix III: Manuscript 
Index, pp. 261-266; Appendix IV: Manuscript Index-Not in the Concordances, pp. 267-268; Appendix V: Typographical and Transcriptional Errors in the Text Editions, p. 269)

Abegg, M.G. - Bowley, J.E. - Cook, E.M., The Dead Sea Scrolls Concordance.

III. The Biblical Texts from the Judean Desert (in consultation with E. Ulrich) (Leiden: Brill 2010).

(Aramaic Concordance, part. 2, pp. 703-720; Greek Concordance: 721-749; Appendix I: Manuscript Index, pp. 753-759; Appendix II: Typographical and Transcriptional Errors in the Text Editions, pp. 760-761)

Abegg, M.G., „Concordance of Proper Nouns in the Non-Biblical Texts from Qumran", The Texts from the Judean Desert: Indices and Introduction to the Discoveries in the Judaean Desert Series (eds. E. Tov et al.) (DJD 39; Oxford: Clarendon 2002) 229-284.

Brown, R.E. et al., A Preliminary Concordance to the Hebrew and Aramaic Fragments from Qumrân Caves II-X (Göttingen: [privately printed] 1988) I-V.

(The first concordance prepared in the 1950s and 60s on the basis of the preliminary transcriptions of the first team of the editors. Manuscript sigla applied to the texts, text identifications and readings were later verified and corrected) Charlesworth, J.H. et al., Graphic Concordance to the Dead Sea Scrolls (PTSDSSP; Tübingen: Mohr Siebeck 1991). (Alphabetic order of the lexemes, not analysed according to their roots)

Dahmen, U., „Nachträge zur Qumran-Konkordanz”, ZAH 4 (1991) 213-235. (This and the following two articles supplement Kuhn's concordance)

Dahmen, U., „Nachträge zur Qumran-Konkordanz”, ZAH 8 (1995) 340-354.

Dahmen, U., ,Weitere Nachträge zur Qumran-Konkordanz”, ZAH9 (1996) 109-128.

Kuhn, K.G., Konkordanz zu den Qumrantexten (Göttingen: Vandenhoeck \& Ruprecht 1960).

Kuhn, K.G., „Nachträge zur ‘Konkordanz zu den Qumrantexten’ unter Mitarbeit von U. Müller, W. Schmücker und H. Stegemann von der Qumranforschungstelle der Universität Heidelberg”, RevQ 4 (1963) 163-234.

Kuhn, K.G., „Konkordanzen und Indizes zu den nicht-biblischen Qumrantexten auf Papier und Microfiche - aus dem Münchener Projekt: Qumran und das Neue Testament", Antikes Judentum und frühes Christentum Festschrift für Hartmut Stegemann zum 65. Geburtstag (eds. H. Stegemann et al.) (BZNW 97; Berlin: de Gruyter 1999) 197-209.

Lignée, H., „Concordance de 'I Q Genesis Apocryphon', 'RevQ 1/2 (1958) 163-186. Martone, C., „A Concordance to the Newly Published Qumran Texts”, Henoch 15 (1993) 155-206.

Richter, H.P., „Konkordanz zu XIQMelkîsédeq (éd. E. Puech)”, RevQ 12/4 (1987) 515-18. 


\section{Electronic Research Tools and Databases}

Accordance Bible Software. Available modules: Qumran-Non-biblical Manuscripts; Qumran-Non-biblical English; DSS Bible - Canonical Order; DSS Bible - Manuscript Order; DSS Bible Greek - Canonical Order; DSS Bible - Manuscript Order; Judean Desert Manuscripts; Greek Judean Desert Manuscripts; Dictionary of Qumran Aramaic (E.M. Cook); Qumran Index; DSS Index (links to DSS Leon Levy Digital Library); Dead Sea Scrolls Images; Biblical DSS Manuscripts Variants; Studies in the Dead Sea Scrolls.

BibleWorks 10 (https://bibleworks.com/) and Logos (https://www.logos.com/). Two Bible software with Qumran modules; in 2018 BibleWorks ceased operation as a provider of Bible software tools but the program still functions as a valuable instrument. Except for a large selection of monographs, Logos software provides the user with several useful Qumran research tools: Lexham Dead Sea Scrolls Hebrew-English Interlinear Bible; Biblical Dead Sea Scrolls: Bible Reference Index; Qumran Sectarian Manuscripts; etc.

Leon Levy Dead Sea Scrolls Digital Library (http://www.deadseascrolls.org.il/ home). Multispectral photographs of the manuscritps freely available online.

Orion Center for the Study of the Dead Sea Scrolls and Related Literature (http:// orion.mscc.huji.ac.il/). The site of the Hebrew University research center; offers helpful resources introducing into the Dead Sea scrolls studies, bibliographic research tools and recent bibliography updated weekly.

Qumran-Wörterbuch Forschungstelle (http://www.qwb.adw-goettingen.gwdg.de/). A project piloted by Reinharda G. Kratz; the goal is the redaction of $\mathrm{He}$ bräisches und aramäisches Wörterbuch zu den Texten vom Toten Meer, two volumes of which have already been published; an electronic database and electronic concordances are part of the project.

Scripta Qumranica Electronica (https://www.qumranica.org/blog/). A joint project of University of Göttingen (Qumran-Wörterbuch), Tel Aviv University (N. Dershovitz), University of Haifa (J. Ben-Dov) and Israel Antiquities Authority (P. Shor, Leon Levy Dead Sea Scrolls Digital Library). Description of the project: Brown-deVost, B., „Scripta Qumranica Electronica (2016-2021)”, HBAI 5 (2016) 307-315.

The Dead Sea Scrolls Electronic Reference Library (Leiden: Brill 1997, 1999, 2006); CD-ROM I: eds. P.S. Aleksander-T.H. Lim; CD II: ed. E. Tov; CD III: ed. E. Tov.

Parry D.W. - Skinner A.C. (eds.), Dead Sea Scrolls Electronic Library Biblical Text, an online edition (in consultation with E. Tov - E. Ulrich) (Leiden: Brill 2015). 


\section{Bibliographic Resources}

Abegg, M.G. - Evans, C.A. - Oegema, G.S., „Bibliography of Messianism and the Dead Sea Scrolls", Qumran - Messianism: Studies on the Messianic Expectations in the Dead Sea Scrolls (eds. J.H. Charlesworth - H. Lichtenberger - G.S. Oegema) (Tübingen: Mohr Siebeck 1998) 204-214.

Burchard, C., Bibliographie zu den Handschriften vom Toten Meer (BZAW 76; Berlin: Töpelmann 1957).

Burchard, C., Bibliographie zu den Handschriften vom Toten Meer: II. NR. 1557-4459 (BZAW 89; Berlin: Töpelmann 1965).

García Martínez, F., „The Temple Scroll: A Systematic Bibliography 1985-1991”, The Madrid Qumran Congress. II. Proceedings of the International Congress on the Dead Sea Scrolls, Madrid 18-21 March, 1991 (eds. J.C. Trebolle Barrera - L. Vegas Montaner) (STDJ 11; Leiden: Brill 1992) 393-403.

García Martínez, F. - Parry, D.W., A Bibliography of the Finds in the Desert of Judah 1970-95: Arranged by Author with Citation and Subject Indexes (STDJ 19; Leiden: Brill 1996).

Jongeling, B., A Classified Bibliography of the Finds in the Desert of Judah 1985-1969 (STDJ 7; Leiden: Brill 1971).

Kapera, Z.J., „Selected Polish Subject Bibliography of the Dead Sea Discoveries", FO 23 (1986) 269-338.

Kapera, Z.J., „Current Bibliography on the Dead Sea Scrolls 1992”, QC 2 (1992-1993) 129-131.

Kapera, Z.J., „Current Bibliography on the Dead Sea Scrolls 1992-1993”, QC 2 (1992-1993) 198-199.

Kapera, Z.J., „Current Bibliography on the Dead Sea Scrolls 1992-1993 (Part III)", QC 3 (1993) 175-207.

Kapera, Z.J., „Current Bibliography on the Dead Sea Scrolls 1994 (Part I)”, QC 4 (1994) 114-124.

Kapera, Z.J., „Current Bibliography on the Dead Sea Scrolls 1994 (Part II)”, QC 4 (1994) 225-248.

Kapera, Z.J., „Current Bibliography on the Dead Sea Scrolls 1994 (Part III)”, QC 5 (1995) 181-192.

Kapera, Z.J., „Current Bibliography on the Dead Sea Scrolls 1995”, QC 5 (1995) 281-94.

Kapera, Z.J., „Current Bibliography on the Dead Sea Scrolls 1996”, QC 6 (1996) 211-246.

Kapera, Z.J., „Current Bibliography on the Dead Sea Scrolls 1997 (Part I)”, QC 7 (1997) 127-144.

Kapera, Z.J., „Current Bibliography on the Dead Sea Scrolls 1997 (Part II)”, QC 7 (1997) 263-287. 
Kapera, Z.J., „Current Bibliography on the Dead Sea Scrolls 1998”, QC 8 (1998) 133-158.

Koester, C., „A Qumran Bibliography: 1974-1984”, BTB 15 (1985) 110-120.

LaSor, W.S., Bibliography of the Dead Sea Scrolls. 1948-1957 (FThSBS 2; Pasadena, CA: Library Fuller Theological Seminary 1958).

Mędala, S., „Recherches sur le problématique des documents de Qumran en Pologne", FO 23 (1985-1986) 269-338.

Muchowski, P., „Bibliography of the Copper Scroll (3Q15)”, FO 26 (1989) 65-70.

Orion Center Bibliography Search (http://orion-bibliography.huji.ac.il/).

Pinnick, A., The Orion Center Bibliography of the Dead Sea Scrolls (1995-2000)" (STDJ 41; Leiden: Brill 2001).

Schuller, E.M. - DiTommaso, L., „A Bibliography of the Hodayot, 1948-1996”, DSD 4 (1997) 55-101.

Stuckenbruck, L.T., „Bibliography on 4QTgLev (4Q156)”, JSP 10 (1992) 53-55. Yizhar, M., Bibliography of Hebrew Publications on the Dead Sea Scrolls 1948-1964 (Cambridge: Harvard University Press 1967).

\section{Editorial Series}

Studies on the Texts of the Desert of Judah (STDJ), Leiden: Brill. For the list of the published volumes, see https://brill.com/view/serial/STDJ.

Biblioteka Zwojów. Tło Nowego Testamentu, Kraków-Mogilany: Enigma Press.

Mędala, S., Wprowadzenie do literatury międzytestamentalnej (BZ.TNT 1; Kraków: Enigma Press 1994).

Betz, O. - Riesner, R., Jezus, Qumran i Watykan (BZ.TNT 2; Kraków: Enigma Press 1996).

Méleze-Modrzejewski, J., Żydzi nad Nilem. Od Ramzesa II do Hadriana (BZ.TNT 3; Kraków: Enigma Press 2000).

Fitzmyer, J.A., 101 pytań o Qumran (BZ.TNT 4; Kraków: WAM - Enigma Press, 1997).

Muchowski, P., Rękopisy znad Morza Martwego: Qumran - Wadi Murabba at - Masada - Nachal Chever, 2nd ed. (BZ.TNT 5; Kraków: Enigma Press 2000).

Milik, J.T., Dziesięć lat odkryć na Pustyni Judzkiej (BZ.TNT 6; Kraków: Enigma 1999).

Muchowski, P., Komentarze do rękopisów znad Morza Martwego (BZ.TNT 7; Kraków: Enigma Press 2000). 
Tronina, A., Biblia w Qumran. Wprowadzenie w lekturę biblijnych rękopisów znad Morza Martwego (BZ.TNT 8; Kraków: Enigma Press 2001).

Stegemann, H., Esseńczycy z Qumran, Jan Chrzciciel i Jezus (BZ.TNT 9; Kraków: Enigma Press 2002).

Teksty z Pustyni Judzkiej, Kraków-Mogilany: Enigma Press

Zdun, P., Pieśni Ofiary Szabatowej z Qumran i Masady (TPJ 1; Kraków: Enigma Press 1996).

Dec, P., Zwój Hymnów Dziękczynnych z Qumran (1QHodayota) (TPJ 2; Kraków-Mogilany: Enigma Press 2017).

Tronina, A., Reguła Zrzeszenia i inne teksty prawne z Qumran. Adnotowany przekład z hebrajskiego 1QS, 1QSa, 1QSb, CD, 1QM (TPJ 3; Kraków-Mogilany: Enigma Press 2017).

Qumranica Mogilanensia, Kraków-Mogilany: Enigma Press. For the list of the published volumes, see http://www.enigmapress.pl/qumranica.php.

\section{Scientific Journals}

Since the study of the Dead Sea scrolls pertains to a vast array of scientific research, many articles that discuss the manuscripts are published in journals belonging to different fields of scholarly research. The four journals listed here publish contributions directly linked with the Dead Sea manuscripts.

Dead Sea Discoveries, 1994-, Leiden: Brill (https://brill.com/view/journals/dsd/ dsd-overview.xml).

Meghillot. Studies in the Dead Sea Scrolls, 2003-, Jerusalem: Hebrew University

- Haifa: University of Haifa (http://megillot.haifa.ac.il/index.php/he/).

Qumran Chronicle, 1990-, Mogilany: Enigma Press (http://www.enigmapress.pl/ chronicle.php).

Revue de Qumrân, 1959-, Leuven: Peeters (http://revuedequmran.fr/index.php/en).

\section{Introductions to the Study of the DSS}

Avery-Peck, A. - Neusner, J. - Chilton, B. (eds.), The Judaism of Qumran: A Systemic Reading of the Dead Sea Scrolls (HdO 57; Leiden: Brill 2001) I-II. Brooke, G.J., Reading the Dead Sea Scrolls: Essays in Method (EJL 39; Atlanta, GA: Society of Biblical Literature 2013).

Brooke, G.J. - Hempel, Ch. (eds.), T\&T Clark Companion to the Dead Sea

Scrolls (London: Bloomsbury T\&T Clark 2019). 
Collins, J.J., Beyond the Qumran Community: The Sectarian Movement of the Dead Sea Scrolls (Grand Rapids, MI: Eerdmans 2010).

Collins, J.J., The Dead Sea Scrolls: A Biography (Princeton, NJ: Princeton University Press 2013).

Cross, F.M., The Ancient Library of Qumran, 3rd rev. and extended ed. (Minneapolis, MN: Fortress 1995).

Dimant, D., The Dead Sea Scrolls in Scholarly Perspective: A History of Research (STDJ 99; Leiden: Brill 2012).

Fitzmyer, J.A., A Guide to the Dead Sea Scrolls and Related Literature (Grand Rapids, MI: Eerdmans 2008).

Grossman, M.L. (ed.), Rediscovering the Dead Sea Scrolls: An Assessment of Old and New Approaches and Methods (Grand Rapids, MI: Eerdmans 2010).

Lange, A., Handbuch der Textfunde vom Toten Meer. I. Die Handschriften biblischer Bücher von Qumran und den anderen Fundorten (Tübingen: Mohr Siebeck 2009).

Lim, T.H. et al. (ed.), The Dead Sea Scrolls in Their Historical Context (Edinburgh: T\&T Clark 2000).

Lim, T.H. - Collins, J.J., The Oxford Handbook of the Dead Sea Scrolls (Oxford: Oxford University Press 2010).

Laperrousaz, E.-M. et al., „Qumran et découvertes au désert de Juda”, Dictionnaire de la Bible: Supplement. IX. Psaumes - refuge (eds. L. Pirot et al.) (Paris: Letouzey \& Ané 1979) 737-1014.

Schiffman, L.H. - VanderKam, J.C. (eds.), Encyclopedia of the Dead Sea Scrolls (New York: Oxford University Press 2000) I-II.

Tyloch, W., Rękopisy z Qumran nad Morzem Martwym, 2nd ed. (Warszawa: Książka i Wiedza 2001).

VanderKam, J.C., Manuskrypty znad Morza Martwego, 2nd ed. (trans. R. Gromacka) (Warszawa: Cyklady 2001).

VanderKam, J.C. - Flint, P., The Meaning of the Dead Sea Scrolls: Their Significance for Understanding the Bible, Judaism, Jesus, and Christianity (San Francisco, CA: HarperSanFrancisco 2002).

VanderKam, J.C., The Dead Sea Scrolls Today, 2nd ed. (Grand Rapids, MI: Eerdmans 2010).

Xeravits, G.G. - Porzig, P., Einführung in die Qumranliteratur (Berlin: De Gruyter 2015). 


\section{History of Discovery}

Brownlee, W.H., „Further Light on Habakkuk”, BASOR 114 (1949) 9-10.

Brownlee, W.H., „The Jerusalem Habakkuk Scroll”, BASOR 112 (1948) 8-18.

Brownlee, W.H., „Muhammad Ed-Deeb's Own Story of His Scroll Discovery”, JNES 16 (1957) 236-239.

Brownlee, W.H., „Edh-Dheeb's Story of His Scroll Discovery”, RevQ 3/4 (1962) 483-494.

Brownlee, W.H., „Some New Facts Concerning the Discovery of the Scrolls of 1Q", $\operatorname{RevQ~4/3~(1963)~417-420.~}$

Fields, W.W., The Dead Sea Scrolls: A Full History. I. 1947-1960 (Leiden: Brill 2009).

Sukenik, E.L., Megillot Genuzot from an Ancient Geniza found in the Judaean Desert: First Reports (Jerusalem: Bialik Foundation 1948). (in Hebrew) (The first overview of the Cave 1 manuscripts)

Trever, J.C. „When Was Qumran Cave 1 Discovered?” RevQ 3/1 (1961) 135-141.

Trever, J.C., The Untold Story of Qumran (Westwood, NJ: Revell 1965).

Trever, J.C., The Dead Sea Scrolls: A Personal Account (Piscataway, NJ: Gorgias Press 2003). 